\title{
Evaluation of Depression and Anxiety of Patients with Multiple Sclerosis During the COVID-19 Pandemic: A Comparison with the General Population
}

\author{
COVID-19 Döneminde Multipl Sklerozlu Hastaların Anksiyete ve Depresyon \\ Düzeylerinin Değerlendirilmesi: Genel Popülasyon ile Karşılaştırılması
}

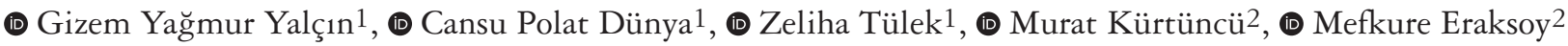 \\ ${ }^{1}$ Florence Nightingale Faculty of Nursing; Istanbul University-Cerrahpasa, Istanbul, Turkey \\ 2Istanbul University, Istanbul Faculty of Medicine, Department of Neurology, Istanbul, Turkey
}

\begin{abstract}
Objective: The coronavirus disease-2019 (COVID-19) pandemic can increase anxiety and depression in patients with multiple sclerosis (PwMS). This study aimed to evaluate the predictors of anxiety and depression in PwMS during the COVID-19 pandemic and compare it with the general population (GP).

Materials and Methods: The study was conducted in an MS clinic in Istanbul University Istanbul Faculty of Medicine. Data were collected online using a form including sociodemographics and questions on COVID-19-related knowledge and the hospital anxiety and depression scale.

Results: This study included 800 participants (GP: 421, MS: 379). Anxiety (42.3\% vs. 32.2\%, p=0.002) and depression $(53.9 \%$ vs. $39.6 \%$, p $<0.001)$ were more common, COVID-19-related knowledge was lower $(9.1 \pm 1.5$ vs. $9.9 \pm 1.2, \mathrm{p}<0.001)$, and rate of COVID-19 infection was higher $(15.4 \%$ vs. $6.9 \%, \mathrm{p}<0.001)$ in the GP than PwMS. Among other factors, COVID-19-related knowledge was a common predictor of anxiety and depression in both GP and MS groups [odds ratio (OR): $0.8,95 \%$ confidence interval (CI) 0.7-0.9, $\mathrm{p}=0.007$ and OR: 0.7, 95\% CI 0.7-0.9, p=0.020, for anxiety; OR: 0.7, 95\% CI 0.7-0.9, p=0.001 and OR: 0.8, 95\% CI $0.7-1.0, \mathrm{p}=0.023$ for depression, respectively].
\end{abstract}

Conclusion: This study revealed that PwMS have less anxiety and depression than the GP. Our study shows the importance of COVID-19-related knowledge and the need for psychological support during the pandemic.

Keywords: Multiple sclerosis, COVID-19, anxiety, depression, COVID-19-related knowledge

$\ddot{O} \mathbf{z}$

Amaç: Koronavirüs hastalığı-2019 (COVID-19) pandemisi multipl skleroz (MS) hastalarında anksiyete ve depresyonu artırabilir. Bu çalışmanın amacı COVID-19 pandemisi sürecinde MS hastalarında anksiyete ve depresyonu değerlendirmek, yordayıcılarını belirlemek ve genel popülasyon (GP) ile karşılaştırmaktır.

Gereç ve Yöntem: Çalışma İstanbul Üniversitesi İstanbul Tip Fakültesi MS kliniğinde yürütüldü. Veriler, sosyodemografik özellikleri, COVID-19 bilgi düzeyini ve hastane anksiyete ve depresyon ölçeğine ilişkin soruları içeren bir form ile online olarak toplandı.

Bulgular: Çalışmaya 800 katılımcı (GP: 421, MS: 379) dahil edildi. Anksiyete (GP: \%42,3 vs. MS: \%32,2, p=0,002) ve depresyon (GP: \%53,9 vs. MS: \%39,6,

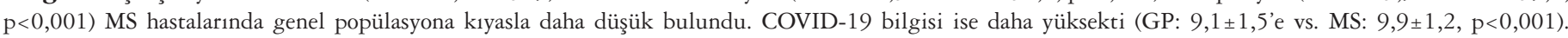
COVID-19 enfeksiyonu geçirme oranı daha düşüktü (GP: \%15,4’e vs. \%6,9, p<0,001). Diğer faktörlerin yanı sıra, COVID-19 hakkında bilgi düzeyi hem GP hem de MS gruplarında anksiyete ve depresyonun ortak bir yordayıcısıdır [anksiyete için odds oranı (OR): 0,8, \%95 güven aralığı (GA): 0,7-0,9, p=0,007 ve OR: 0,7,\%95 GA: 0,7-0,9, p=0,020, depresyon için; OR: 0,7,\%95 GA: 0,7-0,9, p=0,001 ve OR: 0,8, \%95 GA: 0,7-1,0,p=0,023).

Sonuç: Çalışmamız MS hastalarının GP'ye göre daha az anksiyete ve depresyona sahip olduğunu ortaya koydu. Bu çalışma pandemi sürecinde COVID-19'a ilişkin bilgi düzeyinin önemini ve psikolojik destek ihtiyacının gerekliliğini göstermektedir.

Anahtar Kelimeler: Multipl skleroz, COVID-19, anksiyete, depresyon, COVID-19 bilgi düzeyi

Address for Correspondence/Yazışma Adresi: Gizem Yağmur Yalçın Nurse, PhD Student, Florence Nightingale Faculty of Nursing; Istanbul UniversityCerrahpasa, Istanbul, Turkey Phone: +90 5302303822 E-mail: gvizviz@ gmail.com ORCID: orcid.org/0000-0001-8398-9181

Received/Gelis Tarihi: 06.10.2021 Accepted/Kabul Tarihi: 10.12 .2021

${ }^{\circ}$ Copyright 2021 by Turkish Neurological Society

Turkish Journal of Neurology published by Galenos Publishing House. 


\section{Introduction}

Coronavirus disease-2019 (COVID-19) affected and killed millions of people in a short time after its emergence in China and the World Health Organization declaration as a pandemic (1). Turkey is among the most affected countries by COVID-19, with 6,987,494 cases and 62,745 deaths as of September 2021 (2). In our society, where the epidemic had got out of control, public health practices, such as individual measures, quarantine, lockdown, and remote work, became inevitable. The epidemic threatened society in terms of personal health, loss of close relatives, social and occupational life interruption, and economic burden. This threat had negative psychological impacts (fear, stress, insomnia, anxiety, and depression). These psychological impacts have been reported higher among populations with chronic diseases and high-risk groups (3).

Like other individuals with a chronic disease, patients with multiple sclerosis (PwMS) are known to be at risk for anxiety and depression (4). Additionally, the unknown course of immunosuppressed patients with COVID-19, isolation from daily life, and lack of social support due to the lockdown worsened the anxiety and depression of patients $(4,5)$. The COVID-19 pandemic has become a severe stressor in PwMS due to insufficient information at the initial and misinformation in the later stages. Increasing the awareness and elimination of the misinformation may decrease the risks of patients' anxiety and depression.

This study aimed to assess the predictors of anxiety and depression during the COVID-19 pandemic and the effect of COVID-19 awareness on the psychological state of patients compared to the general population (GP).

\section{Material and Methods}

\section{Research Design, Sample, and Setting}

This case-control study was performed in PwMS who were followed up in the outpatient MS clinic at the Istanbul University, Istanbul Faculty of Medicine. Our study included 379 patients who are older than 18 years without a relapse in the last month. The control group consisted of 421 healthy individuals.

\section{Data Collection}

The data were collected using an online survey (Google forms) between October 2020 and February 2021. Participants were asked to complete the questionnaire, which took approximately 15 min, via e-mail or other communication applications. A snowball sampling strategy was used to access the healthy controls.

\section{Data Collection Tools}

An online questionnaire and hospital anxiety and depression scale (HADS) were employed. The questionnaire included sociodemographic and clinical characteristics (duration of diagnosis, drugs used, etc.), questions regarding COVID-19 infection status, and lifestyle changes (medication use, occupation, daily physical activities, sleep, nutrition, etc.). Participants were also assessed for COVID-19-related knowledge (transmission route, protection, etc.). This part of the questionnaire was prepared in line with the COVID-19 Guidelines of the Ministry of Health. Each correct answer was evaluated as one point, and each incorrect or blank answer was evaluated as zero. The total score of the test was calculated by summing the item scores.
The HADS was developed by Zigmond and Snaith (6) and adapted to Turkish by Aydemir et al. (7) This is a 14-item selfassessment four-points Likert scale that evaluates anxiety and depression. The scores range between 0 and 21 . The cut-off score is 10 for anxiety and 7 for depression in the Turkish population.

\section{Ethical Aspect of the Study}

The ethical principle compliance was evaluated by the ethics committee of the institution where the study was conducted, and the Ethics Committee approval was obtained (Istanbul University, Istanbul Faculty of Medicine, Department of Neurology, Istanbul, Turkey, file number: 2020/1095, no: 29624016-050.99- 1215). Consent to participate was obtained using online forms.

\section{Statistical Analysis}

The Statistical Package for the Social Sciences (v 21.0, IBM) software was used for statistical data analysis. Data were analyzed for normality distribution using the Kolmogorov-Smirnov test and expressed as mean ( \pm standard deviation) for continuous variables or frequencies $(\mathrm{n}, \%)$ for categorical variables. Independent samples t-test and One-Way analysis of variance test were used to compare continuous variables between the groups and chi-square test to compare the categorical variables. The Pearson correlation analysis was used to correlate continuous variables and multivariate logistic regression analysis to determine the associated factors with anxiety and depression. The analysis of covariance (ANCOVA) was used to adjust for group differences based on covariates.

\section{Results}

A total of 800 individuals (MS: 379, controls: 421) participated in the study. The mean age of patients was 35.8 9.9 [minimummaximum (min-max): 18-67] years, $67.5 \%(\mathrm{n}=256)$ were female, $50.9 \%(\mathrm{n}=193)$ were married, and $70.4 \%(\mathrm{n}=267)$ had a university degree. The mean age of the controls was 28.6 \pm 8.5 (min-max: 16-65) years, $37.8 \%(n=159)$ were female, $40.4 \%(n=170)$ were married, and 62\% ( $\mathrm{n}=261)$ had a university degree (Table 1$)$.

The mean disease duration was $8.2 \pm 6.6$ (min-max: $1-34$ ) years. During the COVID-19 pandemic, $21.4 \%(n=81)$ of the patients reported an attack, $47.5 \%(n=180)$ were admitted to the hospital due to MS, $13.7 \%(\mathrm{n}=52)$ reported worsening in motor function, and $4.7 \%(\mathrm{n}=18)$ reported starting antidepressants. Interestingly, $13.7 \%(n=52)$ of the patients thought to discontinue their diseasemodifying therapies (DMT) and $12.9 \%(\mathrm{n}=49)$ discontinued their DMT due to fear of getting COVID-19.

More individuals reported changes in their working conditions in the MS group compared to the GP ( $46.6 \%$ vs. $24.9 \%$, p<0.001). The rate of starting smoking during the pandemic was higher in the controls compared to patients $(5.9 \%$ vs. $2.9 \%, \mathrm{p}=0.039)$. The number of COVID-19 infected individuals in the GP was higher than in the PwMS (15.4\% vs. 6.9\%, $\mathrm{p}=0.039)$. The rate of COVID-19 deaths among relatives was higher in the GP than in PwMS (24.7\% vs. $11.9 \%, \mathrm{p}<0.001)$. In both groups, during the COVID-19 pandemic, at least half of the individuals reported changes in their sleeping and eating habits, physical activity, and body weight. The most affected habit was physical activity in both groups. Furthermore, compared to PwMS, insomnia $(\mathrm{p}<0.001)$, eating habits $(p<0.001)$, weight gain $(p<0.001)$, and decreased physical activity $(\mathrm{p}=0.015)$ were more frequent in the GP (Table 2). 
Table 1. Sociodemographic characteristics of participants $(n=800)$

\begin{tabular}{|c|c|c|c|c|c|c|}
\hline Characteristics & $\begin{array}{l}\text { Control } \\
\text { n }\end{array}$ & $\%$ & $\begin{array}{l}\text { PwMS } \\
\mathrm{n}\end{array}$ & $\%$ & $\chi^{2}$ & $\mathrm{p}$ \\
\hline $\begin{array}{l}\text { Age } \\
(\text { Mean } \pm \text { SD }),(\text { min-max })\end{array}$ & $28.6 \pm 8.5$ & $(16-65)$ & $35.8 \pm 9.9$ & $(18-67)$ & 11.1 & $<0.001^{*}$ \\
\hline $\begin{array}{l}\text { Gender } \\
\text { Female } \\
\text { Male }\end{array}$ & $\begin{array}{l}159 \\
262\end{array}$ & $\begin{array}{l}37.8 \\
62.2\end{array}$ & $\begin{array}{l}256 \\
123\end{array}$ & $\begin{array}{l}67.5 \\
32.5\end{array}$ & 70.8 & $<0.001$ \\
\hline $\begin{array}{l}\text { Income } \\
\text { Less than expenses } \\
\text { Equal to expenses } \\
\text { More than expenses }\end{array}$ & $\begin{array}{l}143 \\
218 \\
60\end{array}$ & $\begin{array}{l}34.0 \\
51.8 \\
14.3\end{array}$ & $\begin{array}{l}86 \\
262 \\
31\end{array}$ & $\begin{array}{l}23.1 \\
70.6 \\
8.4\end{array}$ & 29.4 & $<0.001$ \\
\hline $\begin{array}{l}\text { Children } \\
\text { Yes } \\
\text { No }\end{array}$ & $\begin{array}{l}130 \\
291\end{array}$ & $\begin{array}{l}30.9 \\
69.1\end{array}$ & $\begin{array}{l}167 \\
212\end{array}$ & $\begin{array}{l}44.1 \\
55.9\end{array}$ & 14.8 & $<0.001$ \\
\hline $\begin{array}{l}\text { Smoking } \\
\text { Yes } \\
\text { No }\end{array}$ & $\begin{array}{l}154 \\
267\end{array}$ & $\begin{array}{l}36.6 \\
63.4\end{array}$ & $\begin{array}{l}100 \\
279\end{array}$ & $\begin{array}{l}26.5 \\
73.5\end{array}$ & 9.4 & 0.002 \\
\hline $\begin{array}{l}\text { Antidepressant use } \\
\text { Yes } \\
\text { No }\end{array}$ & $\begin{array}{l}15 \\
406\end{array}$ & $\begin{array}{l}3.6 \\
96.4\end{array}$ & $\begin{array}{l}84 \\
295\end{array}$ & $\begin{array}{l}22.2 \\
77.8\end{array}$ & 63.6 & $<0.001$ \\
\hline
\end{tabular}

The mean score of COVID-19-related knowledge was higher in patients than in the GP $(9.9 \pm 1.2$ vs. $9.1 \pm 1.5, \mathrm{p}<0.001)$. Patients had better knowledge, especially on questions regarding transmission routes, whereas their knowledge on protective measures was comparable (Table 3).

Interestingly, the rate of anxiety and depression, when some confounders (age, gender, education, marital status, antidepressant use, COVID-19-related knowledge, and COVID-19 infection status) were adjusted using the ANCOVA, were higher in the GP compared to the patients ( $42.3 \%$ vs. $32.2 \%$ for anxiety, $\mathrm{p}=0.002$; $53.9 \%$ vs. $39.6 \%$ for depression, $\mathrm{p}<0.001$ ) (Figure 1). In line with this observation, anxiety, and depression scores were higher in the controls than PwMS $(8.5 \pm 4.5$ vs. $7.7 \pm 4.5$ for anxiety, $\mathrm{p}=0.005$; $7.7 \pm 4.0$ vs. $6.4 \pm 3.9$ for depression, $\mathrm{p}<0.001)$. Additionally, when correlations among anxiety, depression, and COVID-19-related knowledge were assessed, a significant positive correlation was found between the anxiety and depression scores $(r=0.63, p<0.001)$ and weak negative correlations between anxiety, depression, and knowledge scores (Figure 2). The anxiety and depression scores of participants are shown in Table 4.

The relationship between the patients' clinical features, anxiety, and depression scores revealed no significant correlations between the disease duration, anxiety $(\mathrm{r}=0.81, \mathrm{p}=0.099)$, and depression $(\mathrm{r}=0.01 ; \mathrm{p}=0.781)$. As expected, the anxiety scores of individuals who started using antidepressants during the pandemic period were higher than those who did not use antidepressants (10.2 \pm 5.5 vs. $7.5 \pm 4.4, \mathrm{p}=0.013)$. No significant difference was found in anxiety and depression scores between the patients according to hospital admission status due to worsening MS ( $7.4 \pm 4.5$ vs. $7.9 \pm 4.5$, $\mathrm{p}=0.271$ and $6.6 \pm 3.9$ vs. $6.33 .9, \mathrm{p}=0.377$, respectively). Anxiety and depression scores of patients with relapse were higher than those on remission $(9.1 \pm 4.6$ vs. $7.3 \pm 4.4, \mathrm{p}=0.028$ and $8.1 \pm 3.9$ vs. $6.0 \pm 3.8, \mathrm{p}<0.001$, respectively). The anxiety and depression scores did not differ according to the state of planning to discontinue the DMT $(8.7 \pm 4.2$ vs. $7.5 \pm 4.5, \mathrm{p}=0.065$ and $6.4 \pm 3.3$ vs. $6.5 \pm 4.0$, $\mathrm{p}=0.855$, respectively).

A multivariate logistic regression analysis was performed to determine the predictive factors of anxiety and depression. The model included age, gender, education, marital status, child status, antidepressant use, COVID-19 infection status, loss of relative due to COVID-19, and COVID-19-related knowledge as covariates. The predictors of anxiety include gender (being female) [odds ratio (OR): 1.7, 95\% confidence interval (CI): 1.1-2.7, $\mathrm{p}=0.015]$ and knowledge about COVID-19 in the GP (OR: 0.8, 95\% CI: 0.7-0.9, $\mathrm{p}=0.007)$, and they were age (OR: $0.995 \% \mathrm{CI}: 0.9-1.0, \mathrm{p}=0.010)$, education (OR: $0.3,95 \% \mathrm{CI}: 0.1-0.9, \mathrm{p}=0.025$ ), antidepressant 


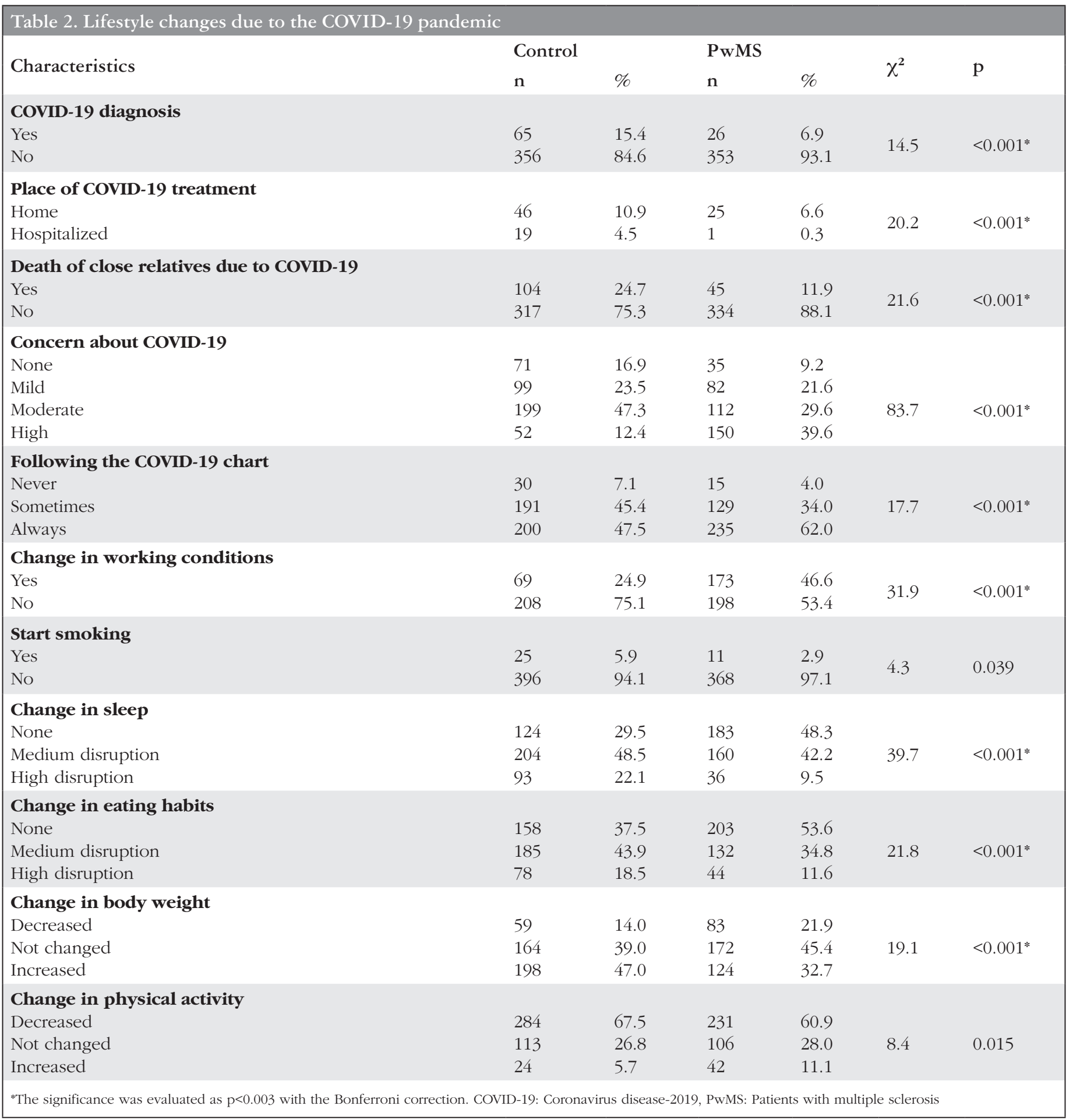

use (OR: 2.2, 95\% CI: 1.3-3.8, p=0.004), and COVID-19-related knowledge (OR: 0.7, 95\% CI: 0.7-0.9, p=0.020) in PwMS (Table 5).

The predictors of depression include loss of relatives due to COVID-19 (OR: 1.8, 95\% CI 0.9-1.0, p=0.010) and COVID-19related knowledge (OR: $1.7,95 \%$ CI 0.7-0.9, $\mathrm{p}=0.001)$ in the GP, whereas education (higher education) (OR: 0.3, 95\% CI: 0.1-0.7, $\mathrm{p}=0.005)$, marital status (being divorced or widowed) (OR: 2.7,
95\% CI: 1.1-7.1, p=0.033), antidepressant use (OR: 2.8, 95\% CI: 1.7-4.8, $\mathrm{p}<0.001$ ), and knowledge on COVID-19 (OR: 0.8, 95\% CI 0.7-1.0, $\mathrm{p}=0.023$ ) (Table 6) in the PwMS.

\section{Discussion}

The COVID-19 pandemic continues to be a burden on public health worldwide. The insufficient known effective treatment at the beginning of the pandemic, the anxiety of getting the 


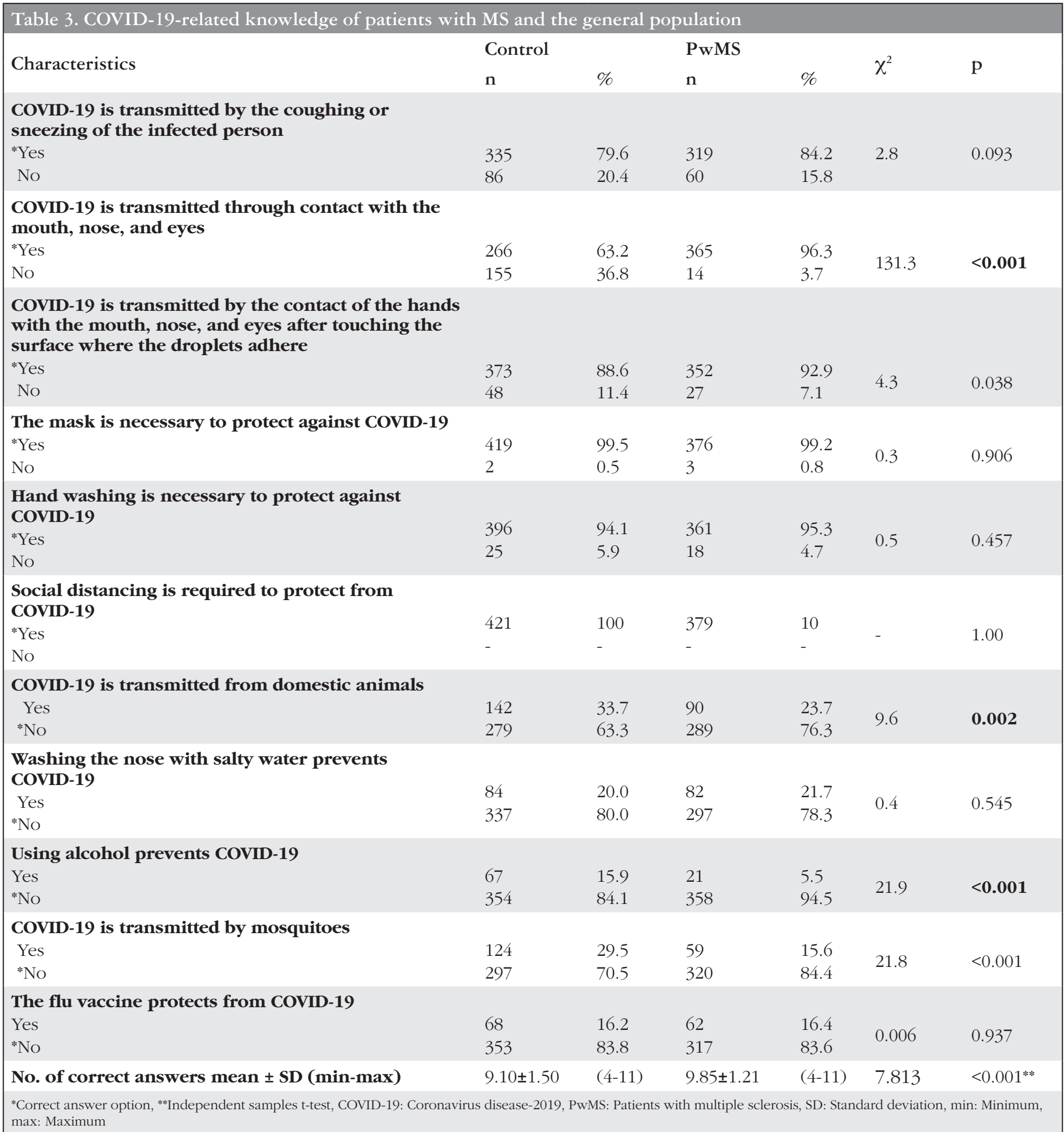

virus, and the uncertainties of the disease caused panic in society. Additionally, social and economic issues arose due to inevitable measures, such as social distancing and lockdown, that further affected the public mental health. This study was carried out during the second wave of the pandemic in Turkey to compare the anxiety and depression levels of PwMS with the GP and evaluate some related factors, including COVID-19-related knowledge.
Studies conducted during the COVID-19 period draw attention to the detrimental psychological effects of the pandemic $(8,9,10)$. A study conducted in China at the beginning of the epidemic revealed that $54 \%$ of the society was psychologically affected, $17 \%$ experienced moderate-severe depression, and $29 \%$ had moderatesevere anxiety symptoms, whereas, in Turkey, 24\% complained of depression, and $45 \%$ of anxiety $(9,11)$. The pandemic caused 

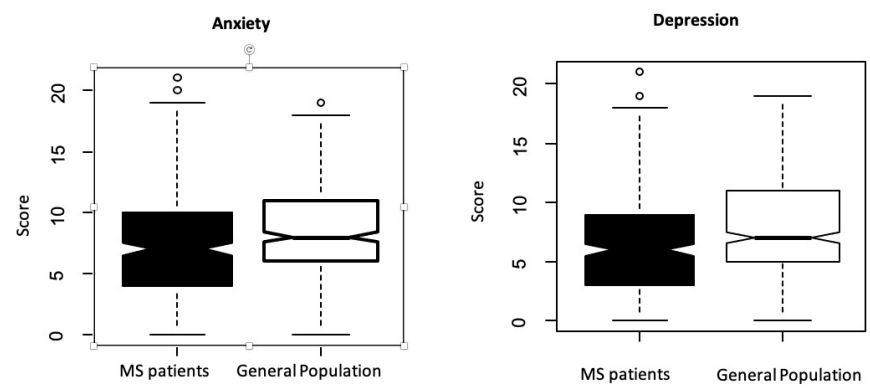

Figure 1. Comparison of the means of anxiety and depression scale scores between patients with MS and controls MS: Multiple sclerosis

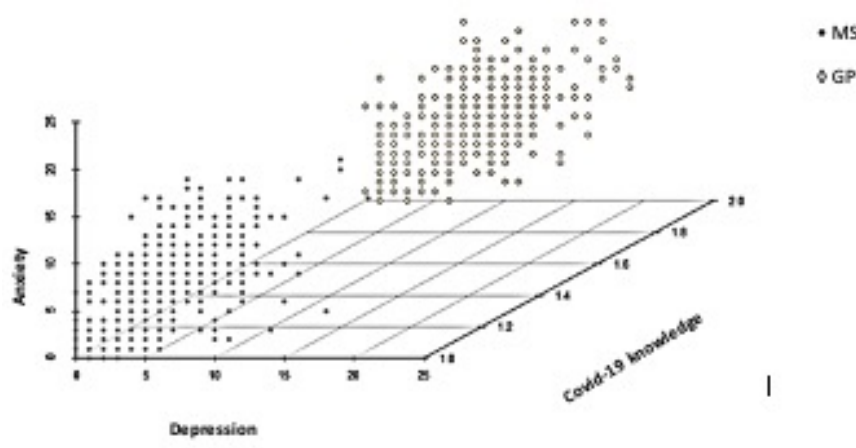

Figure 2. Scatterplot of anxiety and depression scores with COVID-19 knowledge scores

COVID-19: Coronavirus disease-2019, MS: Multiple sclerosis, GP: General population

additional unfavorable psychological effects in individuals with chronic diseases, including MS (4,8). Since the psychological status may alter the immune system, knowledge of the emotional changes of PwMS during the pandemic is critical (12).

Our study revealed that PwMS had increased levels of anxiety (32\%) and depression (40\%) compared to the pre-pandemic period (13). Additionally, we observed that anxiety and depression are related to the sociodemographic and clinical characteristics of patients. Similar to the literature, our study revealed that young age (14), low educational level (15), low income (16), being divorced/ widowed (17), smoking (15), motor disability (16), frequent relapses (18), and antidepressant use (19) were all associated with increased levels of anxiety and depression. The regression models of patients revealed that young age, low educational level, and antidepressant use are predictors of anxiety, whereas low educational level, being divorced/widowed, and antidepressant use for depression. A study (20) revealed that 51\% of patients discontinued their treatments because of anxiety, and this rate was $13 \%$ in our study. Another study reported that $26 \%$ of PwMS stopped their DMT and $13 \%$ decreased their dose without the permission of their health care providers (21).

Our study revealed that $42 \%$ of the general Turkish population had anxiety and $54 \%$ had depression. A previous Turkish study, conducted at the onset of the pandemic, reported that $45 \%$ of the GP had anxiety and $24 \%$ had depression (9). Another study reported mild to moderate depression in $48 \%$ of patients (22). A meta-analysis reported that the prevalence of anxiety was $32 \%$, and the prevalence of depression was $34 \%$ during the COVID-19 period (23). During the pandemic, various studies reported that some sociodemographic characteristics might affect anxiety and depression $(11,22)$. Consistent with previous studies, our study revealed that female gender (9), unemployment (24), low educational level (11), and low income (25) were associated with anxiety and depression. As expected, many studies reported that having COVID-19 and the death of a close relative due to COVID-19 caused worsening in anxiety and depression levels $(11,26)$. Likewise, our study also showed that the female gender was a predictor of anxiety, and the death of a close relative was a predictor of depression.

Contrary to the literature, the anxiety and depression levels of the GP were higher than PwMS when sociodemographic characteristics were adjusted using ANCOVA $(21,27)$ due to acquired adaptability to unexpected conditions in chronic patients and active use of social media. The use of social media has been reported as an effective method in coping with depression in PwMS (28). Additionally, PwMS usually had easier access to their health care providers (i.e., physicians and nurses) during the pandemic, which might positively affect their anxiety and depression. Moreover, the GP's higher levels of anxiety and depression might have been caused by the high rate of unemployment, being single, antidepressant use, COVID-19 infection, and death of close relatives in the GP. It is worth mentioning that the majority of the GP was composed of young male individuals and a significant proportion was unemployed. Considering the gender roles of males in our patriarchal society, we can postulate that the endangered employment status of males might have been perceived as a higher stress factor that cause increased levels of anxiety and depression in the GP.

Another important feature that affects anxiety and depression is COVID-19-related knowledge. As the understanding increases, anxiety and depression are expected to decrease. The COVID-19related knowledge was discovered as a predictor of anxiety and depression in all individuals. As in the literature, the knowledge level of the GP was lower than PwMS in our study (29). Hence, this low-level knowledge may explain the high levels of anxiety and depression in the GP.

The literature reported that the prevalence of COVID-19 was similar in MS and the GP (30). However, our study revealed more COVID-19 cases in the control than in the MS group. Interestingly, the fear of being infected by COVID-19 was lower in PwMS. PwMS have a lower perceived risk of COVID-19 due to their high level protection and isolation compared to controls.

\section{Study Limitations}

Our study has some limitations. First, the groups differ in terms of sociodemographic characteristics. Second, this study was conducted online, thus most participants were young individuals who actively used the technology. Individuals who did not have internet access were excluded from the study. Third, our study shows a momentary status in the constantly changing COVID-19 pandemic. Our study might have underestimated the COVID-19 prevalence because the participation rate of participants with active COVID-19 infection might have been low. 
Table 4. Comparison of anxiety and depression scores of participants according to sociodemographic features and COVID-19 related changes in lifestyle

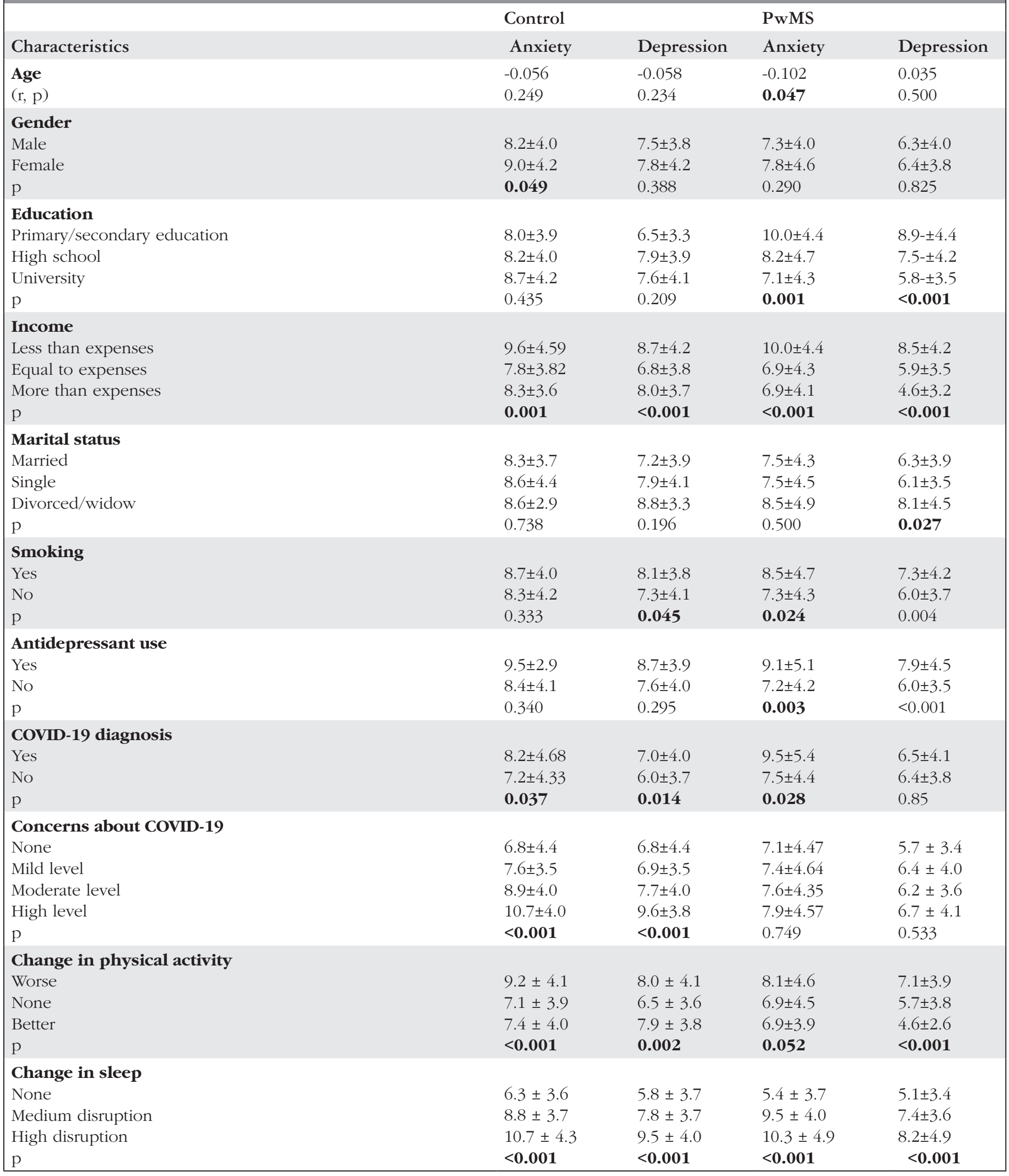




\begin{tabular}{|c|c|c|c|c|}
\hline & Control & & PwMS & \\
\hline \multicolumn{5}{|c|}{ Change in eating habits } \\
\hline Medium disruption & $9.0 \pm 3.9$ & $7.9 \pm 3.6$ & $9.3 \pm 4.2$ & $7.4 \pm 3.3$ \\
\hline High disruption & $10.9 \pm 3.8$ & $9.7 \pm 4.0$ & $10.4 \pm 4.6$ & $8.7 \pm 4.6$ \\
\hline $\mathrm{p}$ & $<0.001$ & $<0.001$ & $<0.001$ & $<0.001$ \\
\hline Decreased & $9.1 \pm 3.9$ & $8.4 \pm 4.3$ & $7.8 \pm 4.4$ & $6.9 \pm 4.1$ \\
\hline Not changed & $7.3 \pm 3.8$ & $6.7 \pm 3.6$ & $6.8 \pm 4.3$ & $5.6 \pm 3.6$ \\
\hline Increased & $9.3 \pm 4.2$ & $8.1 \pm 4.1$ & $8.5 \pm 4.5$ & $7.2 \pm 3.9$ \\
\hline $\mathrm{p}$ & $<0.001$ & 0.001 & 0.005 & 0.001 \\
\hline
\end{tabular}

\begin{tabular}{|c|c|c|c|c|c|c|}
\hline \multirow[b]{2}{*}{ Variables } & \multicolumn{3}{|c|}{ Control } & \multicolumn{3}{|c|}{ PwMS } \\
\hline & OR & $\begin{array}{l}95 \% \mathrm{CI} \\
\text { (lower-upper) }\end{array}$ & $\mathrm{p}$ & OR & $\begin{array}{l}95 \% \mathrm{CI} \\
\text { (lower-upper) }\end{array}$ & $\mathrm{p}$ \\
\hline Age & 0.9 & $1.0-1.0$ & 0.823 & 0.9 & $0.9-0.9$ & 0.010 \\
\hline Gender (female) & 1.7 & $1.1-2.6$ & 0.015 & 1.0 & $0.6-1.7$ & 0.833 \\
\hline \multicolumn{7}{|l|}{ Education } \\
\hline Primary school & - & - & 0.200 & - & - & 0.009 \\
\hline High school & 0.8 & $0.3-1.9$ & 0.627 & 0.3 & $0.1-0.8$ & 0.025 \\
\hline University & 1.2 & $0.5-2.7$ & 0.581 & 0.2 & $0.1-0.6$ & 0.002 \\
\hline \multicolumn{7}{|l|}{ Marital status } \\
\hline Married & - & & 0.800 & - & - & 0.220 \\
\hline Single & 0.8 & $0.1-6.4$ & 0.907 & 1.8 & $0.7-4.8$ & 0.229 \\
\hline Divorced/widow & 0.7 & $0.4-1.6$ & 0.504 & 0.8 & $0.4-1.7$ & 0.600 \\
\hline Having children & 1.3 & $0.6-3.0$ & 0.400 & 1.4 & $0.7-2.9$ & 0.301 \\
\hline Antidepressant use & 1.0 & $0.3-3.1$ & 0.949 & 2.2 & $1.3-3.8$ & 0.004 \\
\hline COVID-19 diagnosis & 1.6 & $0.9-2.9$ & 0.059 & 2.9 & $0.9-5.4$ & 0.085 \\
\hline Loss of relatives due to COVID-19 & 1.1 & $0.7-1.8$ & 0.524 & 1.6 & $08-3.2$ & 0.160 \\
\hline Knowledge of COVID-19 & 0.8 & $0.7-0.9$ & 0.007 & 0.7 & $0.6-1.0$ & 0.020 \\
\hline
\end{tabular}

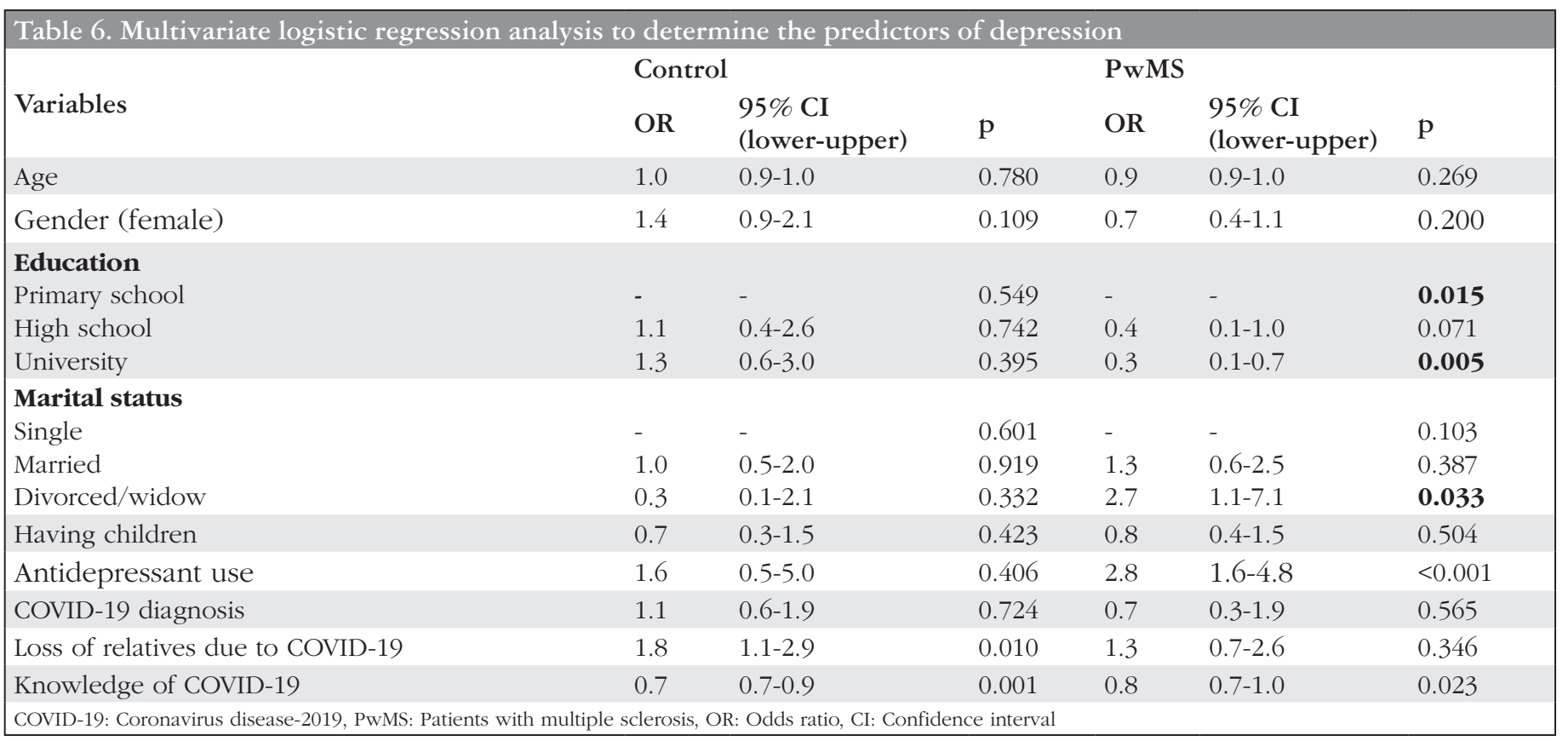




\section{Conclusion}

In conclusion, our study revealed that the COVID-19 pandemic had a significant effect on the anxiety and depression levels of the GP and PwMS. Additionally, the GP had higher levels of anxiety and depression compared to PwMS. Anxiety and depression levels were also determined to be associated with various sociodemographic and clinical characteristics of patients. The female gender was related to anxiety, the death of a close relative due to COVID-19 to depression, and COVID-19-related knowledge to both anxiety and depression in the GP. In PwMS, age was related to anxiety, being single to depression, and low education level, antidepressant use, and COVID-19-related knowledge to both anxiety and depression. Our study emphasizes the importance of psychological support to the GP and PwMS during the pandemic.

\section{Ethics}

Ethics Committee Approval: The ethical principle compliance was evaluated by the ethics committee of the institution where the study was conducted, and the Ethics Committee approval was obtained (Istanbul University, Istanbul Faculty of Medicine, Department of Neurology, Istanbul, Turkey, file number: 2020/1095, no: 29624016-050.99- 1215).

Informed Consent: Consent to participate was obtained using online forms.

Peer-review: Externally peer-reviewed.

\section{Authorship Contributions}

Concept: G.Y.Y., C.P.D., Z.T., M.K., M.E., Design: G.Y.Y., C.P.D., Z.T., M.K. Data Collection or Processing: G.Y.Y., C.P.D., Analysis or Interpretation: G.Y.Y., C.P.D., Z.T., Literature Search: G.Y.Y., C.P.D., Writing: G.Y.Y., C.P.D.

Conflict of Interest: The authors have not declared any conflict of interest related to this article.

Financial Disclosure: No financial support was received from any institution or person for our study.

\section{References}

1. World health organization. Coronovirus disease pandemic. Access date 10.06.2021 Available from: https:/www.who.int/emergencies/diseases/ novel-coronavirus-2019

2. Health TRM of platform of covid-19 information. Access date 10.06.2021 Available from: https://covid19.saglik.gov.tr/.

3. Kendzerska T, Zhu DT, Gershon AS, et al. The Effects of the Health System Response to the COVID-19 Pandemic on Chronic Disease Management: A Narrative Review. Risk Manag Healthc Policy 2021;14:575-584.

4. Capuano R, Altieri M, Bisecco A, et al. Psychological consequences of COVID-19 pandemic in Italian MS patients: signs of resilience? J Neurol 2021;268:743-750.

5. Mantero V, Abate L, Balgera R, et al. Assessing the susceptibility to acute respiratory illness COVID-19-related in a cohort of multiple sclerosis patients. Mult Scler Relat Disord 2020;46:102453.

6. Zigmond AS, Snaith RP. The hospital anxiety and depression scale. Acta Psychiatr Scand 1983;67:361-370.

7. Aydemir Ö, Güvenir T, Kuey L, Kültür S. Validity and reliability of Turkish version of hospital anxiety and depression scale. Turk Psikiyatri Derg 1997;8:280-287.

8. Chiaravalloti ND, Amato MP, Brichetto G, et al. The emotional impact of the COVID-19 pandemic on individuals with progressive multiple sclerosis. J Neurol 2021;268:1598-1607.

9. Özdin S, Bayrak Özdin Ş. Levels and predictors of anxiety, depression and health anxiety during COVID-19 pandemic in Turkish society: The importance of gender. Int J Soc Psychiatry 2020;66:504-511.

10. Wang Y, Di Y, Ye J, Wei W. Study on the public psychological states and its related factors during the outbreak of coronavirus disease 2019 (COVID-19) in some regions of China. Psychol Health Med 2021;26:13-22.

11. Nie XD, Wang Q, Wang MN, et al. Anxiety and depression and its correlates in patients with coronavirus disease 2019 in Wuhan. Int J Psychiatry Clin Pract 2021;25:109-114.

12. Mohr DC, Hart SL, Julian L, Tasch ES. Screening for depression among patients with multiple sclerosis: two questions may be enough. Mult Scler 2007; 13:215-219.

13. Boeschoten RE, Braamse AMJ, Beekman ATF, et al. Prevalence of depression and anxiety in Multiple Sclerosis: A systematic review and meta-analysis. J Neurol Sci 2017;372:331-341.

14. Alschuler KN, Roberts MK, Herring TE, Ehde DM. Distress and risk perception in people living with multiple sclerosis during the early phase of the COVID-19 pandemic. Mult Scler Relat Disord 2021;47:102618.

15. Pham T, Jetté N, Bulloch AGM, et al. The prevalence of anxiety and associated factors in persons with multiple sclerosis. Mult Scler Relat Disord 2018;19:35-39.

16. McKay KA, Tremlett H, Fisk JD, et al. Psychiatric comorbidity is associated with disability progression in multiple sclerosis. Neurology 2018;9:e1316-e1323.

17. Landfeldt E, Castelo-Branco A, Svedbom A, et al. The long-term impact of multiple sclerosis on the risk of divorce. Mult Scler Relat Disord 2018;24:145150.

18. Fisher PL, Salmon P, Heffer-Rahn P, et al. Predictors of emotional distress in people with multiple sclerosis: A systematic review of prospective studies. J Affect Disord 2020;276:752-764.

19. Motolese F, Rossi M, Albergo G, et al. The Psychological Impact of COVID-19 Pandemic on People With Multiple Sclerosis. Front Neurol 2020;11:580507.

20. Alnajashi H, Jabbad R. Behavioral practices of patients with multiple sclerosis during Covid-19 pandemic. PLoS One 2020 22; 15:e0241103.

21. Shaygannejad V, Afshari-Safavi A, Hatef B. Assessment of mental health, knowledge, and attitude of patients with multiple sclerosis and neuromyelitis optica spectrum disorder in response to 2019 novel coronavirus. Neurol Sci 2021;42:2891-2901.

22. Ustun G. Determining depression and related factors in a society affected by COVID-19 pandemic. Int J Soc Psychiatry 2021;67:54-63.

23. Salari N, Hosseinian-Far A, Jalali R, et al. Prevalence of stress, anxiety, depression among the general population during the COVID-19 pandemic: a systematic review and meta-analysis. Global Health 2020;16:57.

24. Shah SMA, Mohammad D, Qureshi MFH, Abbas MZ, Aleem S. Prevalence, Psychological Responses and Associated Correlates of Depression, Anxiety and Stress in a Global Population, During the Coronavirus Disease (COVID-19) Pandemic. Community Ment Health J 2021;57:101-110.

25. Smith L, Jacob L, Yakkundi A, et al. Correlates of symptoms of anxiety and depression and mental wellbeing associated with COVID-19: a crosssectional study of UK-based respondents. Psychiatry Res 2020;291:113138.

26. Mazza MG, De Lorenzo R, Conte C, et al. Anxiety and depression in COVID-19 survivors: Role of inflammatory and clinical predictors. Brain Behav Immun 2020;89:594-600.

27. Costabile T, Carotenuto A, Lavorgna L, et al. COVID-19 pandemic and mental distress in multiple sclerosis: Implications for clinical management. Eur J Neurol 2021;28:3375-3383.

28. Farpour HR, Hoveidaei AH, Habibi L, Moosavi M, Farpour S. The impact of social media use on depression in multiple sclerosis patients. Acta Neurol Belg 2020;120:1405-1409.

29. Sahraian MA, Azimi A, Navardi S, Ala S, Naser Moghadasi A. Evaluation of the rate of COVID-19 infection, hospitalization and death among Iranian patients with multiple sclerosis. Mult Scler Relat Disord 2020;46:102472.

30. Berger JR, Brandstadter R, Bar-Or A. COVID-19 and MS disease-modifying therapies. Neurol Neuroimmunol Neuroinflamm 2020;7:e761. 